Z. Klin. Chem. Klin. Biochem.

12. Jg. 1974, S. $124-127$

\title{
The Quantitative Determination of Thyroxine Binding Globulin by Laurell Electrophoresis
}

\author{
By Th. Kranz, A. Trautwein and A. Sieber \\ From the Behringwerke AG, Marburg/Lahn
}

(Eingegangen am 1. Oktober/5. Dezember 1973)

\begin{abstract}
For the determination of thyroxine binding globulin (TBG) in serum two modifications of Laurell-electrophoresis are presented. The autoradiographic technique requires about 24 hours whereas the staining method only about 5 to 6 hours. The reproducibility of both methods is about 4 to $5 \%$ and the lower limit of sensitivity about $1 / 10$ of mean normal values. - In view of the time saving procedure and the known disadvantages of handling radioisotopes the staining technique is recommended for clinical diagnosis.

Zur Bestimmung von Thyroxin-bindendem Globulin (TBG) in Serum werden zwei Modifikationen der Laurell-Elektrophorese beschrieben. Während für die autoradiographische Methode etwa 24 Stunden erforderlich sind, benötigt die Färbetechnik lediglich 5 bis 6 Stunden. Die Reproduzierbarkeit beider Methoden beträgt etwa 4 bis $5 \%$ und die Nachweisempfindlichkeit etwa $1 / 10$ des gemittelten Wertes von gesunden Spendern. - Wegen der Einfachheit und Schnelligkeit ist die Färbemethode der autoradiographischen Technik, bei der Radioisotope einzusetzen sind, überlegen und für klinische Untersuchungen empfehlenswert.
\end{abstract}

The normal serum concentration range of thyroxine binding globulin (TBG) lies at the lower limit of sensitivity of the normal immunoprecipitation techniques, and therefore its qualitative and quantitative determination by these techniques is difficult.

Freeman and Pearson (1) have used Laurell's "crossed electrophoresis" (2) for the quantitation of TBG by incubating the immunoprecipitate after fixation in the gel with a radioiodine-labelled thyroxine. After removal of the unbound radioactivity by repeated washing, the various arcs delineating thyroxine binding proteins can be measured autoradiographically from the dried gels. However, the identification of the TBG precipitate by the electrophoretic position is not certain because prealbumin, albumin, lipoproteins and the various other thyroxine-binding serum-proteins can also produce similar arcs (1).

Gry Nielsen et al (3) have published recently a method in which the disadvantages of the Freeman-method namely time - wasting washings and the difficulty of identifying TBG - have been overcome by adding limited amounts of iodine-labelled thyroxine to the test solution. Since the binding-constant of TBG for thyroxine is greater than that of all other thyroxine binding serum proteins, as long as the saturation point of TBG is not reached, all the labelled thyroxine is bound to TBG. Only one autoradiographic arc, corresponding to TBG, is then seen on the film. Furthermore, as long as TBG is not saturated with labelled thyroxine, Laurell "rocket" electrophoresis can be carried out even with polyspecific antisera. This technique is more suitable for the routine clinical laboratory because electrophoretic separation is necessary in only one dimension and the test solutions can be applied directly into the antibody-containing gel (rocket technique) (2).

We have improved the quantitative determination of TBG by using an antiserum of high titre in the Laurell "rocket" technique. Evaluation can be made either by autoradiography or by staining the immunoprecipitate with coomassie blue. The results of both methods are compared and the advantages are discussed.

\section{Material and Methods}

The anti-TBG antibody was produced in rabbits. Since no TBG preparation of high purity was available, a TBG-rich interalpha fraction was used for immunization. Therefore, the antiserum is not monospecific and shows a lot of precipitation lines set into immunoelectrophoresis with normal serum (fig. 1).

$1,5 \%$ agarose was dissolved and boiled with stirring in a barbitone buffer $0.02 \mathrm{~mol} / 1$, pH 8.6 (buffer-contents: 4.12 .g sodiumbarbital, $0.8 \mathrm{~g}$ barbital and 11 dest. water - Merck, Darmstadt). The mixture was cooled to $56^{\circ} \mathrm{C}$ and anti-TBG-serum was incorporated to a final concentration in the gel of $0.5 \%$ (autoradiography) or $1.2 \%$ (staining). The antibody-containing gel was spread as a $1.5 \mathrm{~mm}$ thick layer on glass slides (e. g. $15 \mathrm{ml}$ for $10 \times 10 \mathrm{~cm}$ ) and allowed to set.

$5 \mu l$ of the test-solution was instilled into wells of $2.5 \mathrm{~mm}$ diameter. Electrophoresis was carried out for 3 hours at 8 to 10 volts per $\mathrm{cm}$ with cooling to about $15^{\circ} \mathrm{C}$ using the equipment manufactured by Dansk Laboratorieudstyr, Copenhagen, obtainable from Behringwerke AG, Marburg/Lahn, Germany. A pooled serum from 200 donors was used as the standard serum.

In the autoradiographic method the standard serum was applied to each plate in dilutions of $1: 5,1: 7,1: 11$ and $1: 21$. The optimal dilution for the test sera was found to be $1: 11$. Before applica :ion to the gel plate, sufficient $\left[{ }^{125} I\right] L$-thyroxine (Farbwerke toechst AG, Frankfurt/Main) to give a total activity of 15 to $2.0 \mathrm{nCi}$ in $5 \mu$, was added in the smallest possible volumes ${ }^{1}$ )

\footnotetext{
1) For this reason the specific activity should be about $100 \mathrm{mCi} / \mathrm{mg}$.
} 


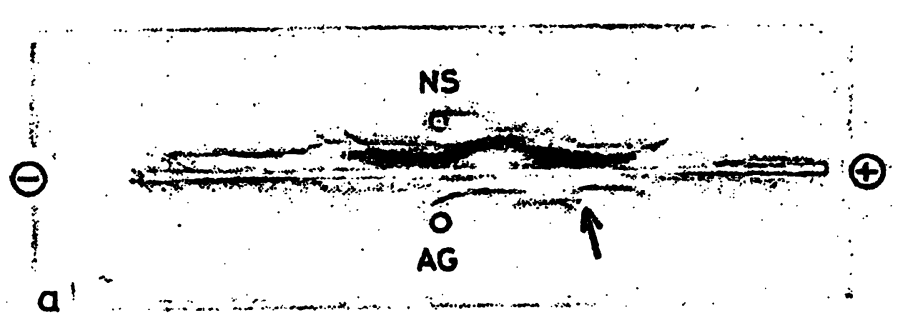

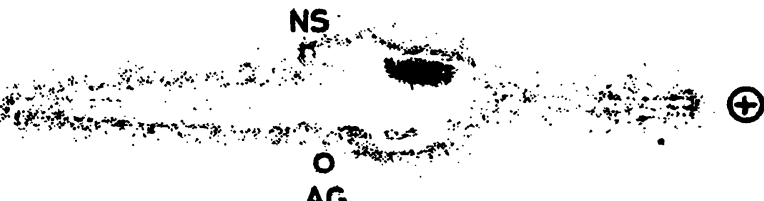

b

AG

Fig. 1. Immunological characterization of the anti-TBG-serum. Immunoelectrophoretic pattern of the antiserum (AB) with normal human serum (NS) and the interalpha fraction immunized with (AG).

a) coomassie brilliant blue staining

b) autoradiography after incubation with $\left[{ }^{125} I\right] L$ Thyroxine.

TBG precipitation lines in the stained gel are not visible distinctly; the blackening in autoradiographic presentation marks the blurred line between the two well stained arcs (see arrow).

to both the control and test-solutions. After completion of the electrophoretic run, the gel was covered with porous filterpaper and dried in a warm air stream for about $\mathbf{3 0}$ minutes. For autoradiography the slide with the dried gel was exposed to a photographic plate (Kodak safety film 'Kodirex for radiography') overnight and developed in a bath for 4 minutes (G 7 p, Agfa-Gevaert, Leverkusen, Germany).

The staining method using coomassie brilliant blue (E. Gurr, Ltd., Cressex Ind. Estate, High Wycombe, Bucks., U. K.) required $5 \mu$ l of undiluted serum samples to be applied to the wells. The TBG content of the previously mentioned pooled serum was doubled by the addition of a TBG-rich fraction, and this was then applied undiluted, and diluted $1: 2$ and $1: 4$ in order to plot the standard curve. Following the electrophoretic run the plate was prepared for staining: the gel was covered with porous filter-paper (avoiding air bubbles) and then with a 1-2 cm layer of absorbent cellulose tissue which was pressed onto the gel for approximately 15 minutes $^{2}$ ) by means of a glass plate loaded with about $1 \mathrm{~kg}$. The filter-paper was then removed and the gel washed twice with $0.1 \mathrm{~mol} / 1 \mathrm{NaCl}$ solution and finally with distilled water for 15 minutes. After covering the gel with a fresh layer of a filter-paper, it was dried in a warm airstream for about $\mathbf{3 0}$ minutes. - For staining, the dried gel was placed in the staining bath $(0,5 \%$ coomassie brilliant blue in a solvent consisting of $10 \%$ glacial acetic acid, $45 \%$ ethanol $(96 \%)$ and $45 \%$ distilled water) for about 60 minutes $^{2}$ ). Excess dye was removed by two washings, each of about 15 minutes, using the solvent mentioned above.

The height of the precipitates in the agarose gel varied from 5 to $50 \mathrm{~mm}$ depending on the TBG content or dilution of the test solution.

\section{Results and Discussion}

An autoradiogram showing standards and a series of sera from patients with thyroid disease, is shown in figure 2. The standard curve is seen in figure 3. Assuming

2) W. Becker: Methods of Qualitative and Quantitative Immunoelectrophoresis, Farbwerke Hoechst AG, Behring Department, Frankfurt/M., p. 12 (1972).

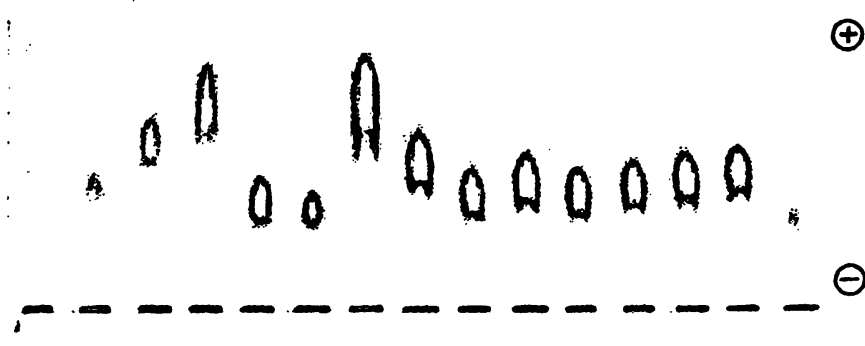

Fig. 2. Autoradiographic presentation of the TBG-content in a series of patient sera.

The first four probes belong to standard serum in dilutions $1: 21,1: 11,1: 7$ and $1: 5$; the remaining probes to patients' sera diluted tn 1:7.

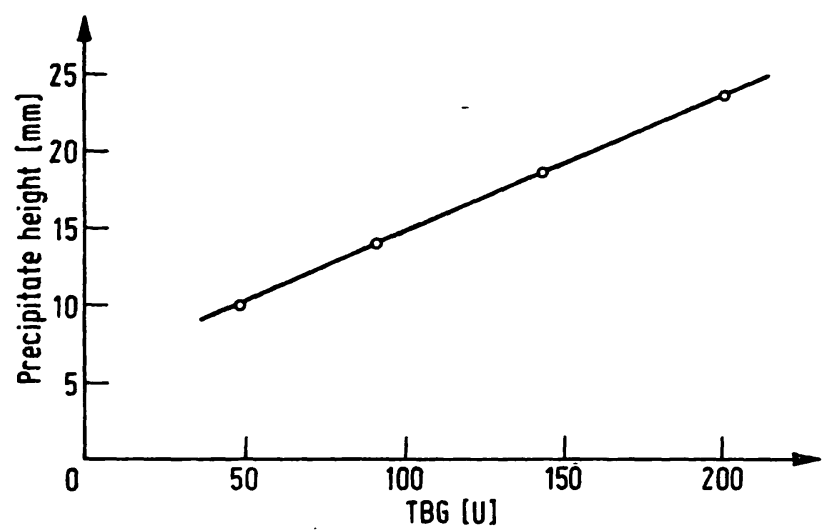

Fig. 3. Standard curve from autoradiographic plates. Standardization on the basis of a mean normal value of $100 \mathrm{U}$ TBG.

a value of 100 units $(U)$ for our standard pool of healthy adult sera, the values of patients' sera range from $40 \mathrm{U}$ to $230 \mathrm{U}$. Figure 4 shows a plate which has been evaluated by staining with coomassie blue. The relevant standard curve is seen in figure 5 . In addition to the three primary standards $(50,100$ and $200 \mathrm{U}$ ) four further sera of known values in the range between 100 and $200 \mathrm{U}$ were applied as controls. The values obtained are depicted as crosses on the diagram (fig. 5); they range from 98 to $105 \%$ of the nominal value. In the low concentration range (below 50 U TBG) the standard curve shows minor deviations from a straight line so that the curve can not be simply extrapolated without the use of further diluted standard solutions. Under the conditions described, the staining method gives satisfactory results for values down to $10 \mathrm{U}$ TBG. 


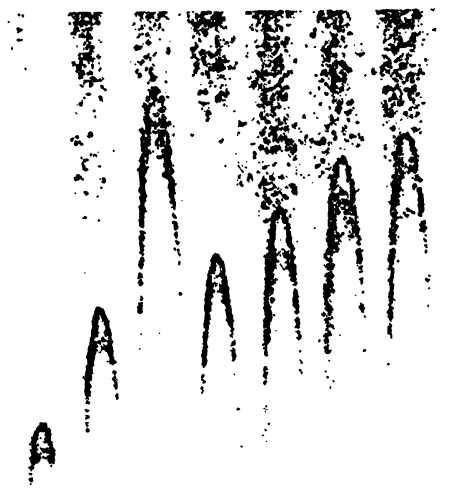

:

\section{-}

Fig. 4. Electrophoresis gel after staining with coomassie brilliant blue.

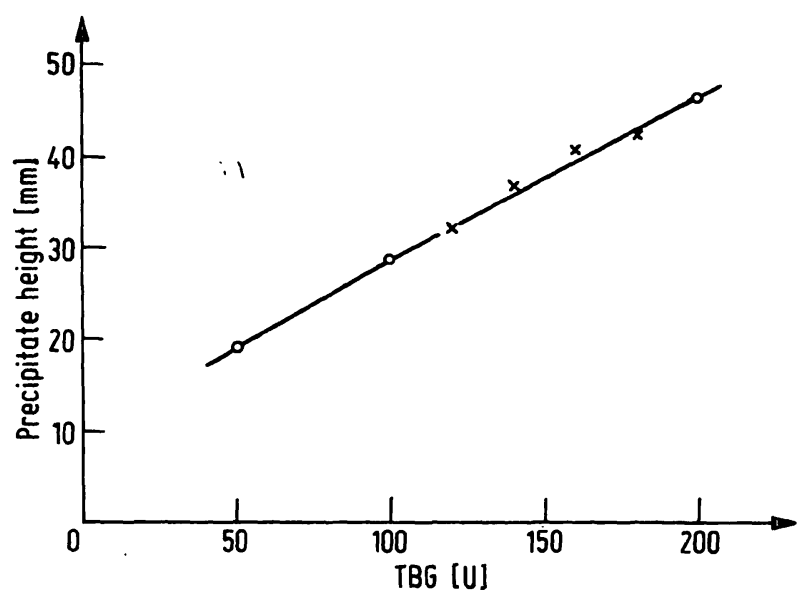

Fig. 5. Standard curve showing reproducibility of various dilutions.

The reproducibility of the rockets obtained from standard solutions used in five plates on one day was about $\pm 3 \%$ (staining) and $\pm 8 \%$ (autoradiography) (tab. 1); the reproducibility of the methods using two control sera on nineteen different days was $\pm 4.9 \%$ (staining) or $4.4 \%$ (autoradiography).

The normal range obtained from the same group of about 60 sera from healthy persons by both the staining and autoradiographic method is given in table 2 . The greater standard deviation and coefficient of variation using the autoradiographic technique is most probably a result of poor contrast photography. - The correlation of the values achieved with both methods was very good: similarly, a comparison of the values obtained with 65 sera gave a coefficient of correlation of $r=0.93$. The diagram of frequency (fig. 6) shows that the grouping of the values obtained from patients with thyroid disorders varies significantly from that of healthy persons. Further investigations should prove the TBG-estimation to be particularly useful in clinical diagnosis.

The sensitivity of the autoradiographic and staining methods are identical. In our studies staining with
Tab. 1. Reproducibility of the TBG-determination

\begin{tabular}{|c|c|c|c|c|c|}
\hline \multicolumn{5}{|c|}{ Standard solutions*) } & $\begin{array}{l}\text { control serum } \\
\text { TBG }\end{array}$ \\
\hline \multicolumn{6}{|c|}{ a) Staining method with coomassie blue } \\
\hline $\begin{array}{l}\text { TBG } \\
\mathbf{N} \\
\bar{x} \\
\pm s \\
V_{K}\end{array}$ & $\begin{array}{c}50 \mathrm{U} \\
5 \\
21.6 \mathrm{~mm} \\
0.4 \mathrm{~mm} \\
\pm 1.7 \%\end{array}$ & $\begin{array}{c}100 \mathrm{U} \\
5 \\
30.9 \mathrm{~mm} \\
0.6 \mathrm{~mm} \\
\pm 1.9 \%\end{array}$ & $\begin{array}{c}200 \mathrm{U} \\
5 \\
48.0 \mathrm{~mm} \\
1.3 \mathrm{~mm} \\
\pm 2.6 \%\end{array}$ & $\begin{array}{l}- \\
- \\
-\end{array}$ & $\begin{array}{r}9 \\
81 \mathrm{U} \\
4 \mathrm{U} \\
+4.9 \%\end{array}$ \\
\hline \multicolumn{6}{|c|}{ b) Autoradiographic method } \\
\hline $\begin{array}{l}\text { dilution } \\
\mathbf{N} \\
\overline{\mathbf{X}} \\
\pm \mathrm{s} \\
\mathrm{V}_{\mathrm{K}}\end{array}$ & $\begin{array}{c}1: 21 \\
5 \\
10.4 \mathrm{~mm} \\
0.9 \mathrm{~mm} \\
\pm 8.3 \%\end{array}$ & $\begin{array}{c}1: 11 \\
5 \\
14.9 \mathrm{~mm} \\
1.1 \mathrm{~mm} \\
\pm 7.5 \%\end{array}$ & $\begin{array}{c}1: 7 \\
5 \\
19.3 \mathrm{~mm} \\
1.0 \mathrm{~mm} \\
\pm 4.8 \%\end{array}$ & $\begin{array}{c}1: 5 \\
5 \\
24.0 \mathrm{~mm} \\
0.6 \mathrm{~mm} \\
\pm 2.6 \%\end{array}$ & $\begin{array}{c}1: 1 \text { (undil.) } \\
14 \\
96 \mathrm{U} \\
4 \mathrm{U} \\
\pm 4.4 \%\end{array}$ \\
\hline
\end{tabular}

*) evaluation on five plates run on one day

Tab. 2. Mean values in healthy persons

\begin{tabular}{lccc}
\hline & & $\begin{array}{c}\text { staining } \\
\text { method }\end{array}$ & $\begin{array}{l}\text { autoradiographic } \\
\text { method }\end{array}$ \\
\hline number of sera & $\mathrm{N}$ & 63 & 65 \\
mean*) & $\overline{\mathrm{x}}$ & $89 \mathrm{U}$ & $82 \mathrm{U}$ \\
standard deviation & $\pm \mathrm{s}$ & $14 \mathrm{U}$ & $17 \mathrm{U}$ \\
coefficient of variation & $\mathrm{V}_{\mathrm{K}}$ & $15.5 \%$ & $20.2 \%$ \\
\hline
\end{tabular}

*) Units on the basis of reference serum equals $100 \mathrm{U}$

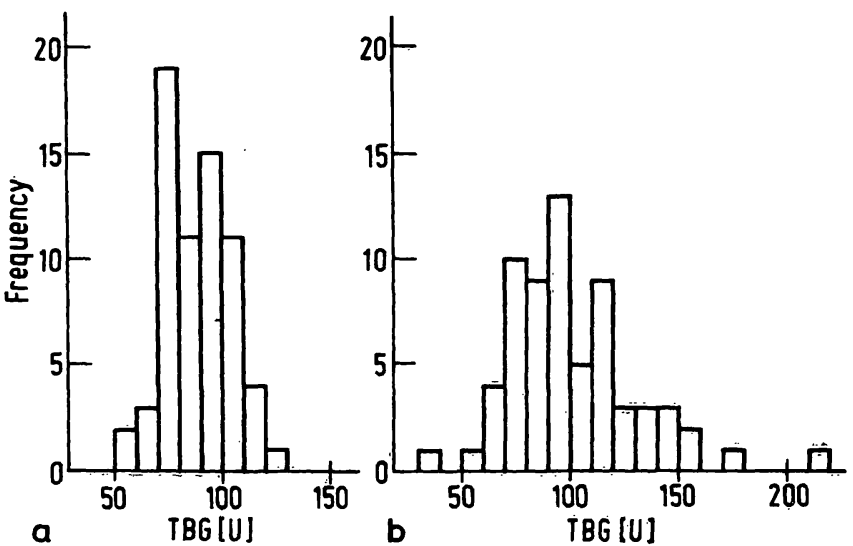

Fig. 6a/b: Distribution diagram of the TBG-content in about 65 sera each, of healthy persons a); and patients with thyroid disorders b)

coomassie blue gave better reproducibility and - above all - required less time. The autoradiographic exposure alone takes about 16 hours, as compared to only 5 to 6 hours for the complete staining technique, inclusive of the electrophoretic run, consecutive washing, staining and drying. Furthermore, as there is no necessity to handle radioisotopes with their attendant difficulties TBG-estimations can be easily performed in every clinical laboratory.

\section{Acknowledgement}

The authors wish to thank Miss Marianne Spyra, Miss Gudrun Mengel and $P$. Cieplik for their technical assistance. 


\section{References}

1. Freeman, T. \& Pearson, J. D. (1969), Clin. Chim. Acta 26, 365-368.

2. Laurell, C. B., (1972), Scand. J. Clin. Lab. Invest. 29, Supp. 124, 1-136.

3. Gry Nielsen, H., Buus, O. \& Weeke, B. (1972), Clin. Chim. Acta 36, 133-138.

Dr. Th. Kranz

Behringwerke AG

3550 Marburg/Lahn 